\title{
Woordeboeke en Dowe gebruikers: huidige probleme en die behoefte aan beter oplossings*
}

\author{
Hanelle Fourie Blair, Buro van die Woordeboek van die Afrikaanse Taal, \\ Stellenbosch, Suid-Afrika en Departement Afrikaans en Nederlands, \\ Universiteit Stellenbosch, Stellenbosch, Suid-Afrika \\ (hfourie@sun.ac.za)
}

Opsomming: Gebaretaalleksikografie is 'n afdeling van die leksikografie wat tot dusver 'n grootliks vae, onbelangrike area was. Die ontwikkeling van gebaretaalleksikografie was in die verlede onderhewig aan verskillende vooroordele en beperkinge. Dit was dikwels nie nodig geag om ' $n$ tweetalige woordeboek saam te stel waarin dit ook moontlik is om 'n gebaar op te soek nie aangesien tweetalige gebaretaalwoordeboeke grotendeels gemik was op horende persone wat die taal wou of moes leer. Daarby was dit baie moeilik vanweë die aard van gedrukte woordeboeke en die gebrek aan 'n ortografiese vorm van gebaretaal om gebare op 'n manier voor te stel én te rangskik sodat hulle opgesoek kan word sonder om van 'n geskrewe soekterm gebruik te maak. Daar is wel notasiesisteme ontwikkel in 'n poging om hierdie probleem te omseil, maar hierdie sisteme het nooit by gewone gebruikers wyd byval gevind nie. Die ontwikkeling van elektroniese gebaretaalwoordeboeke het egter gesorg vir 'n revolusie in gebaretaalleksikografie. Dit is nie meer ongewoon om elektroniese gebaretaalwoordeboeke te vind waarin nie net ' $n$ woord nie, maar ook 'n gebaar soekbaar is, gewoonlik volgens een of meer van die gebaar se parameters, soos handvorm. Sulke woordeboeke maak dit moontlik vir 'n Dowe gebruiker om direkte toegang tot sy of haar eerste taal (gebaretaal) te bekom sonder enige kennis van die tweede taal (die geskrewe taal). Die artikel verwys ook na 'n nuutvoorgestelde model wat dit vir baie jong Dowe gebruikers moontlik maak om ook via konsep na gebaar of woord te soek.

Sleutelwoorde: GEBARETAAL, LEKSIKOGRAFIE, WOORDEBOEK, GEBAREPARAMETERS, GEBARENOTASIE, ELEKTRONIESE WOORDEBOEKE, DOWE TEIKENGEBRUIKERS, GELETTERDHEID, GEBRUIKERSITUASIE, WOORDEBOEKKULTUUR

\footnotetext{
Abstract: Dictionaries and Deaf Users - Current Problems and the Need for Better Solutions. Sign language lexicography is a branch of lexicography that has until now been a largely vague, unimportant area. The development of sign language lexicography has in the past been subject to various forms of bias and limitation. Often it was not considered necessary to compile a bilingual dictionary in which it is also possible to look up a sign because bilingual sign language dictionaries were mostly aimed at hearing people who wanted to or had to learn the language. In addition to that it was very difficult, owing to the nature of printed dictionaries and the

* Hierdie artikel is 'n uittreksel uit 'n D.Litt.-proefskrif, ' $n$ Leksikografiese model vir 'n elektroniese tweetalige grondslagfasewoordeboek van Suid-Afrikaanse Gebaretaal en Afrikaans, wat in Maart 2013 deur die Universiteit Stellenbosch, Stellenbosch, Suid-Afrika, aanvaar is.
} 
lack of a sign language orthography, to present and order signs so that they may be searched without using a written search term. Some notation systems were developed in an effort to circumvent this problem, but these systems never found widespread acceptance with regular users. The development of electronic sign language dictionaries however have caused a revolution in sign language lexicography. It is no longer unusual to find electronic sign language dictionaries in which it is not only possible to search for a word, but also for a sign, usually according to one or more of the sign's parameters, like handshape. Such dictionaries make it possible for a Deaf user to obtain direct access to his or her first language (sign language) without any knowledge of the second language (the written language). The article also points out a newly proposed model for very young Deaf users which allows them to also search for a sign or word via concept.

Keywords: SIGN LANGUAGE, LEXICOGRAPHY, DICTIONARY, SIGN PARAMETERS, SIGN NOTATION, ELECTRONIC DICTIONARIES, DEAF TARGET USERS, LITERACY, USER SITUATION, DICTIONARY CULTURE

\section{Inleiding}

Die gemiddelde Dowe ${ }^{1}$ gebruiker ervaar verskeie probleme in die gebruik van woordeboeke: die opvoedkundige agtergrond van Dowes is gewoonlik (en ook universeel - alhoewel daar altyd uitsonderings is) van uiteenlopende gehalte en die gemiddelde Dowe volwassene bereik die (geskrewe) geletterdheidsvlak van 'n leerder in graad vyf. Woordelyste of woordeboeke wat 'n geskrewe taal en gebaretaal kombineer maar wat slegs toegang in een rigting bied - dus van 'n geskrewe woord $n a$ 'n gebaar - faal die Dowe gebruiker wie se eerste taal gebaretaal is of wat verkies om gebaretaal eerder as 'n geskrewe of gesproke taal te gebruik. Sulke woordelyste en woordeboeke vereis van Dowe gebruikers om deur die tweede taal, waarin hulle gewoonlik slegs baie lae geletterdheidsvlakke het, toegang tot hulle eerste taal te bekom en daaroor te leer, en dui op 'n oorheersende fokus op horende-Dowe kommunikasie sonder om Dowehorende kommunikatiewe behoeftes in ag te neem. Dit skep 'n ongebalanseerde en onregverdige gebruikersituasie wat waarskynlik nie in baie ander taalgemeenskappe geduld sou word nie. Tog is dit 'n algemene situasie in die arena van horende-Dowe kommunikasie regoor die wêreld.

Die ideaal sou dus wees om tweetalige en tweerigtinggebaretaalwoordeboeke saam te stel wat dit nie net moontlik maak om 'n gebaar deur middel van 'n sekere woord op te soek nie, maar ook om 'n woord deur middel van 'n gebaar op te soek. So 'n woordeboek sou nie slegs baie nuttiger wees vir 'n Dowe gebruiker wat die geskrewe taal enkodeer nie, maar dit sou ook nuttig wees vir die horende gebruiker wat gebaretaal wil dekodeer.

Hierdie artikel sal 'n kort oorsig verskaf van die uitdagings, geskiedenis en tradisies van gebaretaalleksikografie, 'n verduideliking van die notering van gebare, en 'n bespreking van elektroniese gebaretaalwoordeboeke en hulle vermoë om tweetalige, tweerigtingwoordeboeke aan te bied wat baie gebruikersvriendelik is. Dit sal ook verwys na 'n nuwe model wat dit nie net moontlik maak om van woord na gebaar en van gebaar na woord te beweeg nie, maar ook van konsep na gebaar/woord, soos voorgestel deur Fourie (2013). 


\section{Gebaretaalleksikografie}

Die gebaretaalleksikograaf moet verskeie uitdagings oorkom. Eerstens is daar geen ortografie of skryfwyse vir gebaretale nie. Alhoewel verskeie notasiesisteme reeds ontwikkel is, word geen van hulle algemeen gebruik nie en is die meeste te ingewikkeld en kompleks om gebare in 'n woordeboek weer te gee in ieder geval vir die algemene gebruiker. Tweedens is daar in byna alle lande slegs 'n paar gebarebronne waaruit die betekenis(se) en grammatikale eienskappe van gebare afgelei kan word en waaruit gebruiksfrekwensies van gebare bepaal kan word. Derdens verskil gebaretale aansienlik van gesproke tale. Aangesien die gebaretaal 'n komplekse struktuur kan hê waar die gesproke taal 'n eenvoudige woord het en ook selfs omgekeerd, is dit dikwels moeilik om ' $n$ woord-vir-gebaar- of gebaar-vir-woord-ekwivalent te gee (Zwitserlood 2010: 444-445). Laastens moet gebaretaalleksikograwe die nalatenskap van 'n tradisie van onvoldoende samestelling van gebaretaalwoordeboeke deur nieleksikograwe oorkom - om hierdie rede het die bestaande gebaretaalwoordeboeke in Suid-Afrika dikwels hewige kritiek ontvang en word dit selde indien ooit deur die Dowe gemeenskap gebruik.

\section{Tradisies in gebaretaalleksikografie}

The word [dictionary] suggests authority, scholarship, and precision. (Landau 1984: 5)

Alhoewel gebaretale baie jare - en in sommige gevalle, steeds - as ondergeskikte of mindere tale gesien is, het 'n verskeidenheid eenvoudige gebaretaalwoordeboeke in die verlede verskyn. Hierdie boeke is gewoonlik gerig op (horende) onderwysers en ouers wat nodig het om met hul Dowe leerlinge of kinders te kommunikeer wanneer gesproke kommunikasie faal. Die meeste van hierdie woordeboeke, wêreldwyd sowel as in Suid-Afrika, is tipies saamgestel deur onderwysers, maatskaplike werkers, spraakterapeute, lede van verskeie godsdienstige instansies, e.s.m. Tot ongeveer die middel 1960's is die meeste gebaretale nie eens as volwaardige tale vergelykbaar met gesproke tale gesien nie, maar danksy die publikasie in 1965 van die eerste uitgawe van Stokoe, Casterline en Croneberg se gebaretaalwoordeboek, gebaseer op taalkundige beginsels, het gebaretaalleksikografie stadig momentum begin kry (Schermer 2004: 2). Sodra gebaretaalnavorsing in ' $n$ land behoorlik posvat, is een van die eerste take wat aangepak (moet) word, gewoonlik die samestelling van 'n woordeboek.

Die woordeboeke tot dusver bestaan oor die algemeen uit tweetalige woordelyste wat 'n basiese stel geskrewe woorde uit die gesproke taal bevat tesame met 'n skets of foto van 'n persoon wat die gebaar by elke woord demonstreer. Baie min, indien enige, inligting word oor die gebaar gegee en dit is ook nie ongewoon om meer as een gebare-ekwivalent per woord aan te tref nie (bv. Penn et al. 1992-1994). Sulke woordeboeke is noodwendig eenrigting, van die gesproke taal na die gebaretaal, en is volgens die alfabet, temas, of beide, gerangskik. 
Namate gebaretaal meer geredelik as natuurlike tale aanvaar is en daar ' $n$ groter behoefte was om hulle aan te leer, was daar ook 'n groter behoefte aan meer woordeboeke met meer gebare en 'n uitvoeriger bewerking van die gebare. Hierdie woordeboeke, dikwels saamgestel deur professionele leksikograwe, het steeds dieselfde formaat: hulle heet gewoonlik "Die X Gebaretaalwoordeboek" (waar X staan vir 'n land of streek), hulle is tweetalig en gewoonlik ook eenrigting (met enkele uitsonderings). Die meeste woordeboeke bied steeds een woord vir een gebaar en bevat baie min addisionele inligting oor die gebare (Zwitserlood 2010: 445).

Voorbeelde van die mees gesofistikeerde tweerigting- en tweetalige gebaretaalwoordeboeke in boekvorm sluit in Johnston se Auslan Dictionary (1989), Brien se Dictionary of British Sign Language/English (1992), Radutzky se woordeboek van Italiaanse Gebaretaal (1992) en Malm se Finse Gebaretaalwoordeboek (1998). Hierdie woordeboeke bied die leksikon van 'n gebaretaal deur middel van 'n geordende reeks hoofgebare, wat daaropvolgend in die tweede taal verduidelik word. Dit vereis ' $n$ gedetailleerde analise van die fonemiese eienskappe van gebare (Schermer 2004: 4).

Om werklik reg aan die rykheid en oorvloed van die leksikon van gebaretale te laat geskied, is dit eintlik nodig om eers eentalige woordeboeke te skep. Tweetalige woordeboeke behoort op die eentalige woordeboekinligting gebaseer te word om die vertaalstruikelblokke tussen die gebaretaal en die gesproke taal van 'n gemeenskap te vermy (Schermer 2004: 4). Ongelukkig is so 'n benadering nie noodwendig prakties of ekonomies haalbaar nie en daarby is dit nie ongewoon vir 'n "klein" taal se eerste woordeboek om 'n tweetalige woordeboek te wees nie.

\section{Gebareparameters}

Om die volgende besprekings van die notering van gebare te kan begryp, is dit belangrik om 'n duidelike begrip van die parameters of "boublokke" van gebare te hê. Notasiesisteme beskryf gebare tipies as 'n kombinasie van hulle kleinste kontrastiewe komponente. Die term vir hierdie komponente is "chereme" (Stokoe et al. 1976: xxix), soortgelyk aan die foneme in gesproke tale. Dit is afgelei van die Griekse woord vir "hand". Gebare word volgens handvorm, beweging, plek van artikulasie, ens. geklassifiseer. Die chereme wat belangrik is om individuele gebare te identifiseer en te onderskei, is die volgende gebareparameters:

1. die handvorm wat gebruik word om die gebaar te vorm,

2. die plasing of plek van die gebaar in ruimte,

3. die oriëntering van die handpalms, en

4. die tipe beweging wat deur die hande uitgevoer word (Mesthrie et al. 2000: 420). 
Die bostaande parameters word soos volg deur Howard (2008) vir SASL ${ }^{2}$ uiteengesit en geilllustreer:

Die handvorms in figuur 1 is: Plat Hand, Toe Plat Hand, B (dus die vingerspelvorm van die letter B), Gebuigde Plat Hand, Gebuigde Toe Plat Hand, Gebuigde B, Oop 5, Gebuigde 5 (of 'n klou-handvorm), V, Gebuigde V, O, Plat O, C, Gebuigde C, F, Plat F, 1, 2.
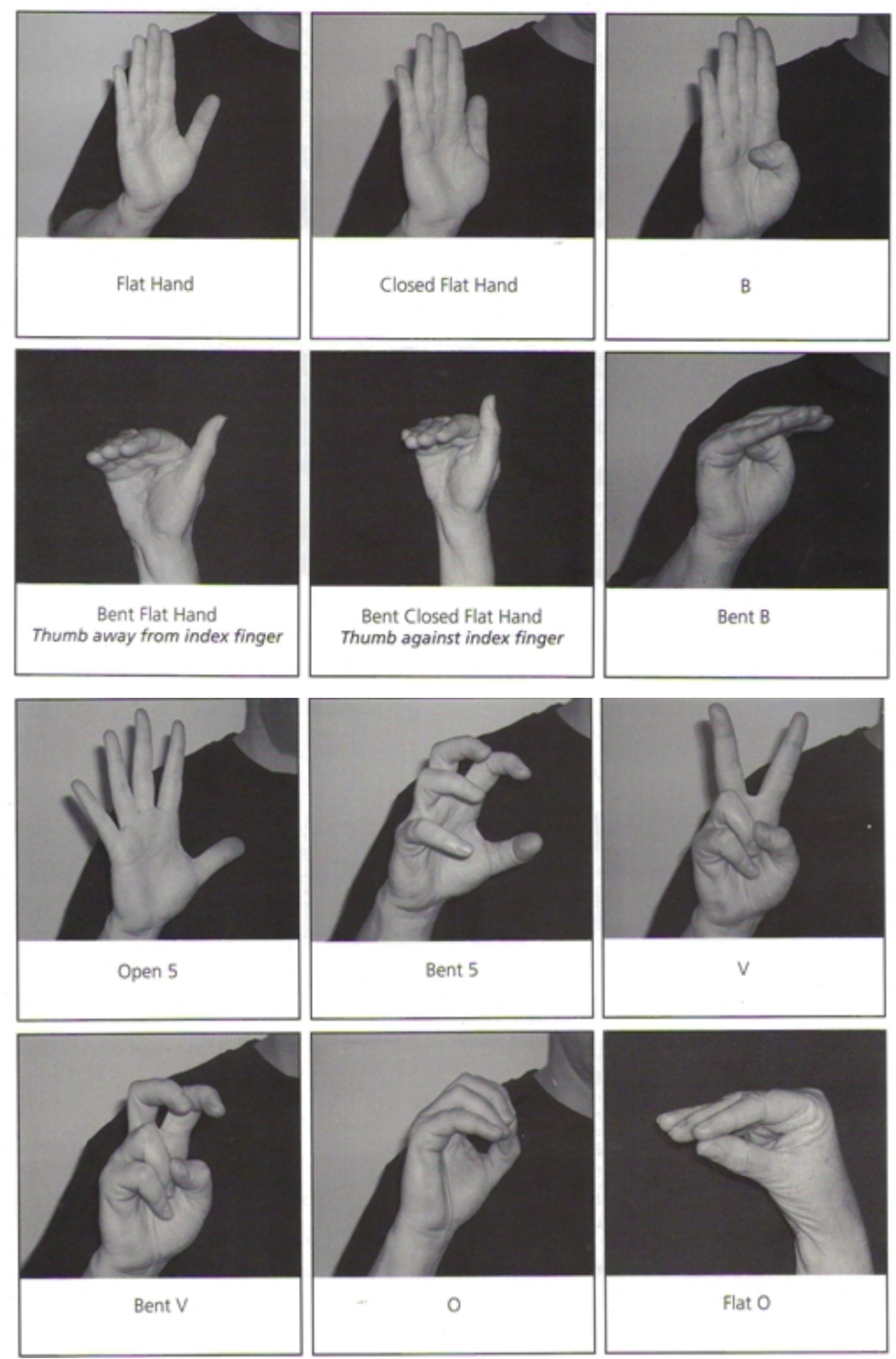

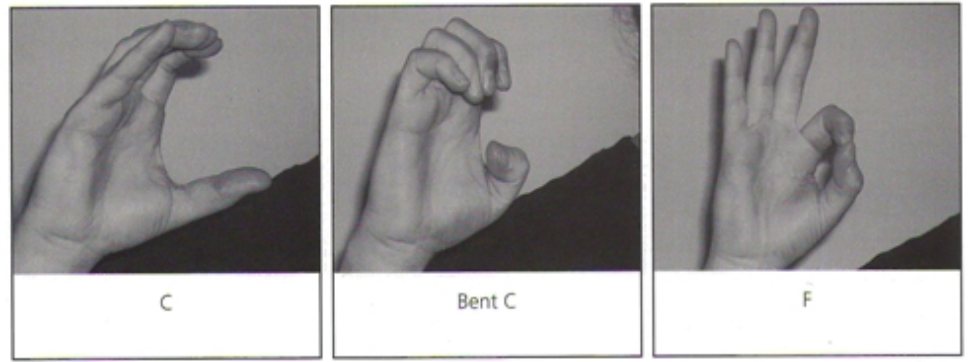

Figuur 1: Handvorms (Howard 2008: 4-6)

Die parameterwaardes ten opsigte van handpalmoriëntering in figuur 2 is: Palm Op, Palm Af, Palm Links, Palm Regs, Palm Teenoorstaande (Bors), Palm Weg en Palms Na Mekaar:
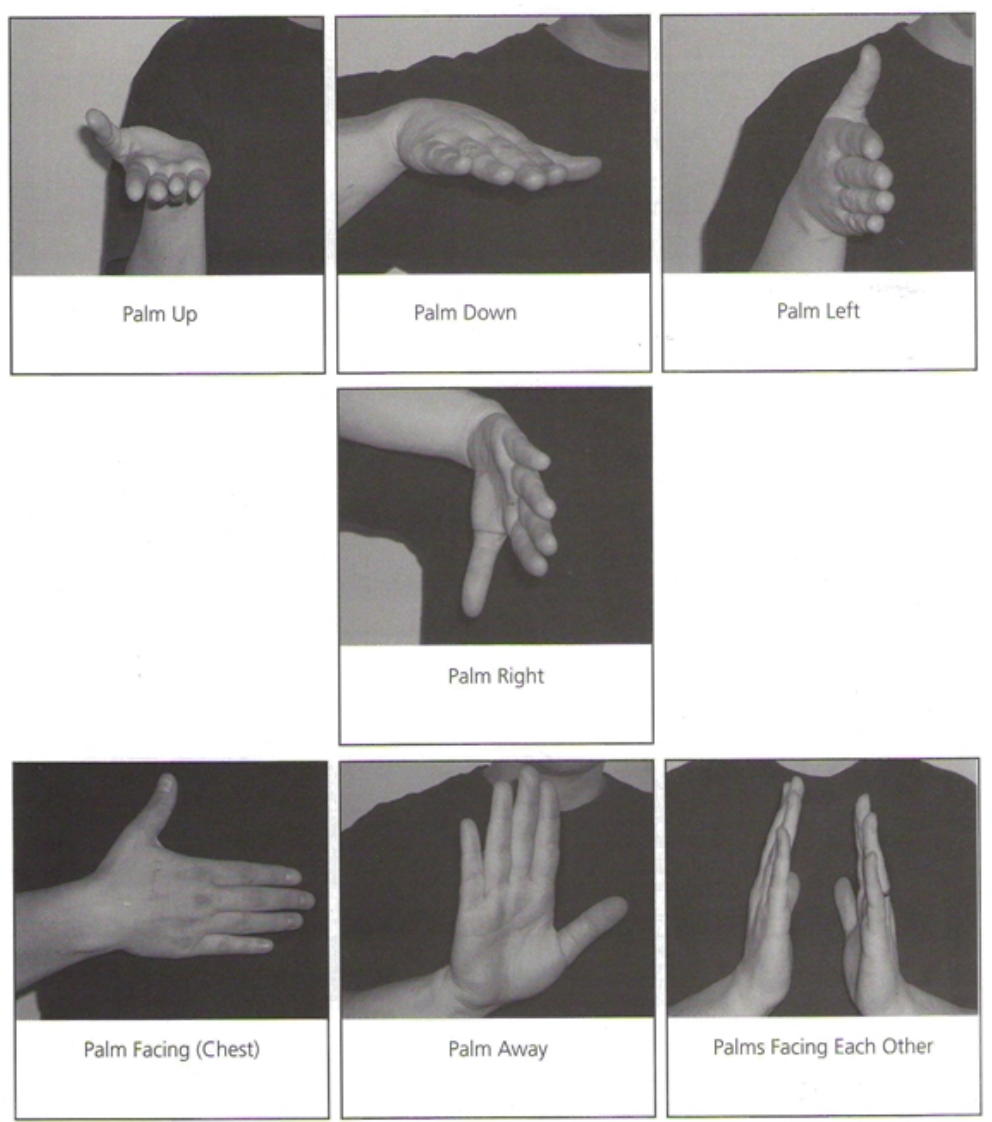

Figuur 2: Handpalmoriëntering (Howard 2008: 7) 
Die parameters van Ruimte/Plek en Beweging word soos volg beskryf:

Ruimte/Plek - Die ruimte direk voor jou liggaam word die neutrale ruimte genoem. Gebare in die Finger Talk-woordeboek bevat inligting oor die presiese plek waar die gebaar uitgevoer word. Ruimte word in gebaretaal op 'n soortgelyke manier gebruik as wat volume in gesproke taal ingespan word: hoe groter die ruimte wat gebruik word, hoe "harder" praat jy, hoe kleiner die ruimte, hoe "sagter" is jou stem.

Beweging - dit is die manier waarop die hande tydens die gebaar beweeg word, insluitende die rigting waarin hulle beweeg.

Gebaretale maak egter nie net gebruik van handgebare om betekenis oor te dra nie, en ander liggaamsdele speel ook ' $\mathrm{n}$ rol in taalproduksie. Natuurlike gebaretale gebruik ook kenmerke wat nie met die hande gevorm word nie (bv. gesigsuitdrukkings, lipbewegings, liggaamshouding, oriëntering en beweging van die kop of liggaam) om morfologiese en grammatikale kategorieë aan te dui (Mesthrie et al. 2000: 420). Trouens, verskillende gesigsuitdrukkings kan verskillende betekenisse aan dieselfde gebaar gee, en die gebrek aan ' $n$ meegaande gesigsuitdrukking kan lei tot 'n ongrammatikale uitdrukking. Dit is dikwels een van die aspekte wat horende gebruikers van 'n gebaretaal die moeilikste aanleer: aangesien horendes meestal selfbewus is weens die oordrewe gesigsuitdrukkings van gebaretaal kom hulle uitinge dikwels "stomp" en "dood" voor, soms tot die vermaak van Dowe gespreksgenote en soms tot hulle verwarring.

Die niemanuele eienskappe (NME's of "Non Manual Features", m.a.w. grammatikale elemente wat nie op die hande verskyn nie, soos hierbo beskryf word), is volgens Howard (2008) se beskrywing die volgende:

Die NME's ${ }^{3}$ in figuur 3 is: Neutraal, Gelukkig, Hartseer, Geskok, Moeg, Lui, Verras, Gefrustreerd, Kwaad, Ontsteld, Bang, Trots, Verveeld, Depressief, Opgewonde, Nukkerig, Heftig, Pynlik, Afkeer, Vraend, Geniet, Smaaklik (lippe rond saamgepers), Smaaklik (lippe plat saamgepers), Vasberade, Verbaas, Aggressief, Onplesierig.

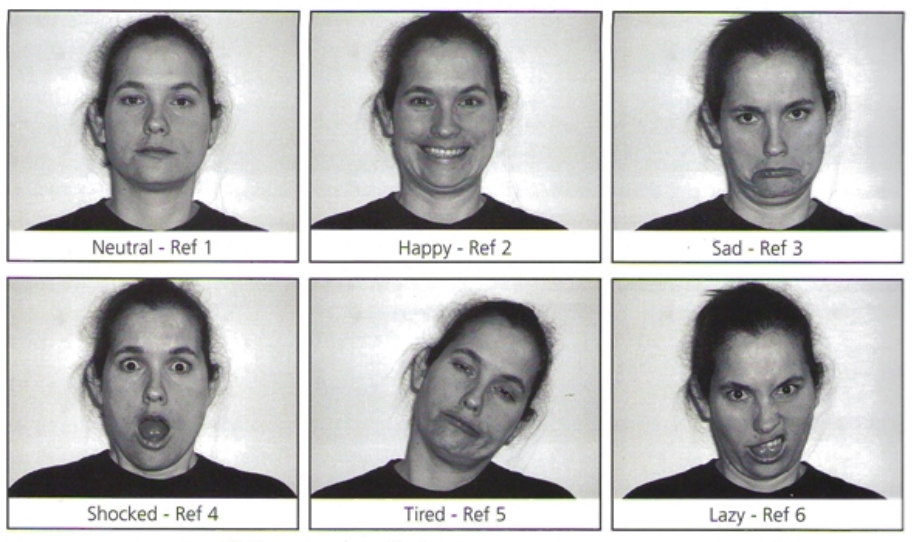




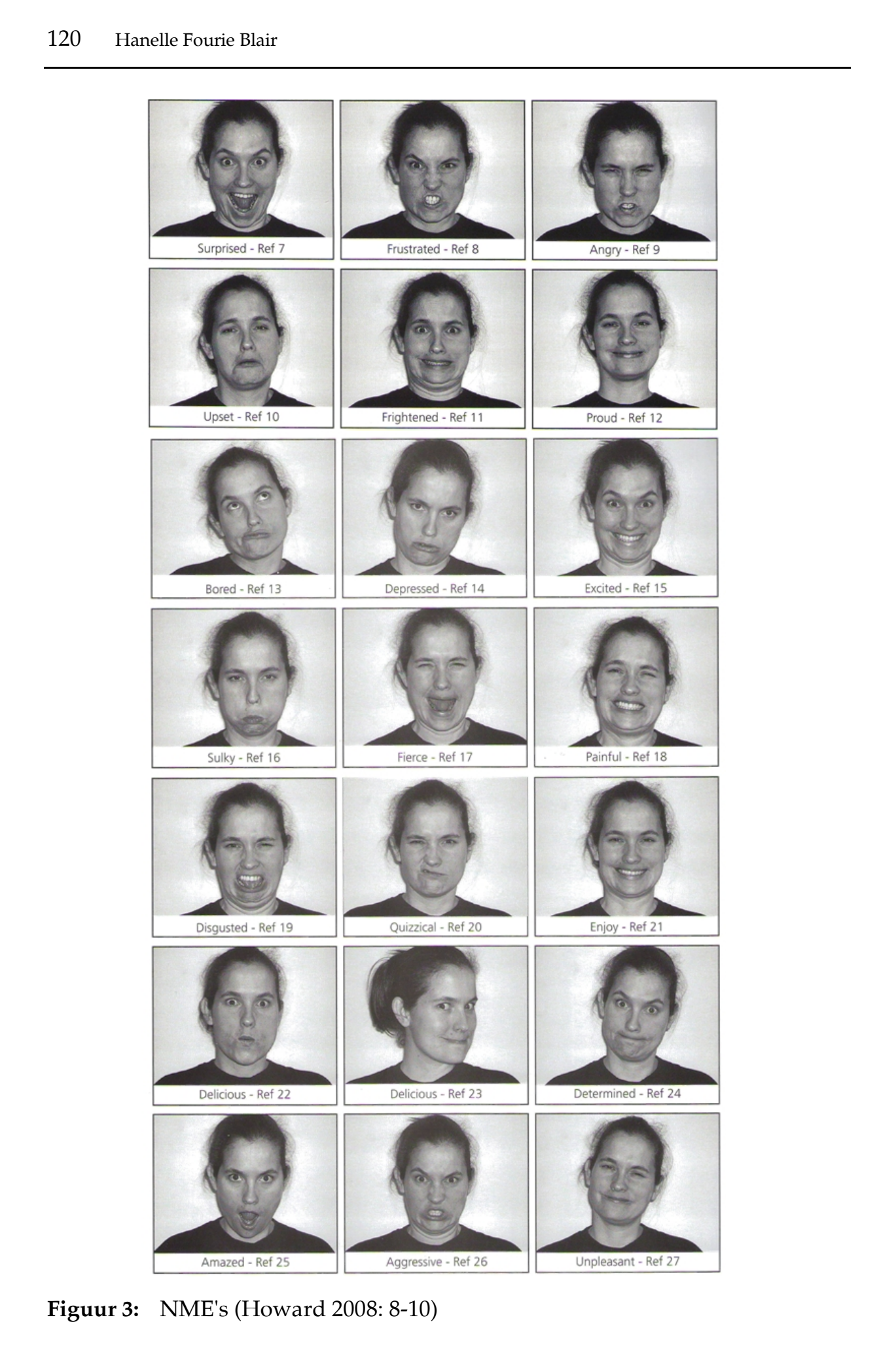




\section{Die notasie van gebare}

Woordeboeke van gesproke tale het gewoonlik te make met tale wat wel oor 'n geskrewe vorm beskik - gesproke tale is vanweë hul aard eendimensioneel (spraakklanke word een na die ander uitgespreek) en dit word gereflekteer in die lineêre volgorde van letters in die geskrewe vorm. Sommige woordeboeke bevat ook inligting oor die uitspraak van 'n woord, gewoonlik aan die hand van fonetiese notasie, of gee minstens 'n aanduiding van die lettergrepe en klem vir elke woord.

In teenstelling hiermee beskik gebaretale nie oor enige geskrewe vorm nie, en aangesien spraakklanke nie ' $n$ rol in hierdie tale speel nie, bied die fonetiese skryfwyse ook geen uitkoms nie. Die probleem met gebaretaalnotasie is dat 'n vierdimensionele taalsein (gebare gebruik driedimensionele ruimte asook ' $n$ sekwensiële of temporele struktuur) moeilik is om in 'n statiese voorstelling weer te gee. Woordeboeksamestellers het hierdie probleem gewoonlik op verskillende wyses hanteer, waarvan een die gebruik is van prentjies/sketse of foto's van 'n persoon wat die gebaar demonstreer. Gebarenotasie word in sommige woordeboeke gebruik, maar gewoonlik saam met die grafiese voorstelling van die gebaar. Danksy meer onlangse tegnologie is die probleem ook omseil deur die gebruik van video-uitbeeldings in elektroniese woordeboeke - elkeen van hierdie metodes het 'n impak op die organisasie van die woordeboek (Zwitserlood 2010: 447).

Die meeste woordeboeke, veral die gedrukte woordeboeke, gebruik sketse of foto's om die gebare voor te stel. In die verlede was dit die enigste moontlikheid vir voorstelling en die afbeeldings is gewoonlik so gekies om selfs vir die ongesofistikeerde gebruiker verstaanbaar te wees. Die aktiwiteit van 'n gebaar is egter nie sigbaar in 'n stilbeeld nie, en die aktiwiteit of beweging word gewoonlik daargestel deur pyltjies en ander ekstra simbole wat op die prent aangebring word, of voorgestel deur 'n reeks beelde soos in figuur 4 .

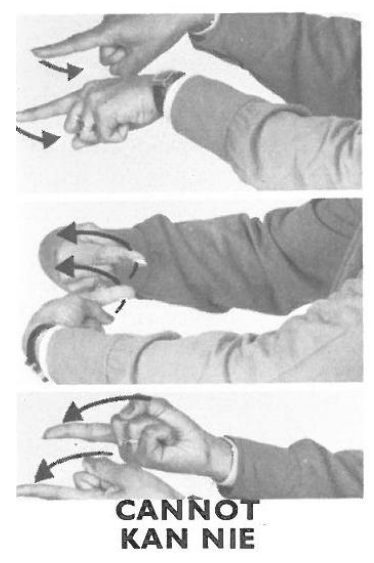

Figuur 4: Voorbeeld van 'n reeks beelde met pyltjies om beweging aan te dui (Nieder-Heitmann 1980: 109) 
Voorstellings met bygevoegde simbole vir aktiwiteite of beweging is steeds nie baie uitvoerig of gedetailleerd nie, veral nie oor die deel van die gebaar wat nie op die hande plaasvind nie. Daarby neem sulke voorstellings baie ruimte in beslag en is steeds nie maklik om te gebruik nie. Ekstra inligting oor die gebaar se uitvoering is in sommige woordeboeke bygevoeg om 'n oplossing hiervoor te bied (figuur 4 en veral figuur 5 en 7), maar dit dra eintlik slegs by tot die probleem van ruimte - die feit dat afbeeldings soveel ruimte in beslag neem, maak dit feitlik onmoontlik om inligting oor lemmas in die gebaretaal (dus deur middel van afbeeldings) te verskaf. Om hierdie rede bestaan daar geen gedrukte tweetalige woordeboek van 'n gesproke taal na 'n gebaretaal wat inligting oor die lemmas in gebaretaal verskaf nie, en nog minder ' $n$ eentalige gebaretaalwoordeboek. Sommige woordeboeke maak van 'n baie meer minimalistiese metode gebruik en verskaf slegs ' $n$ diagram van die gebaar onder ' $n$ geskrewe soekwoord in ' $n$ alfabetiese lys, sonder enige verdere grammatikale inligting (figuur 7).

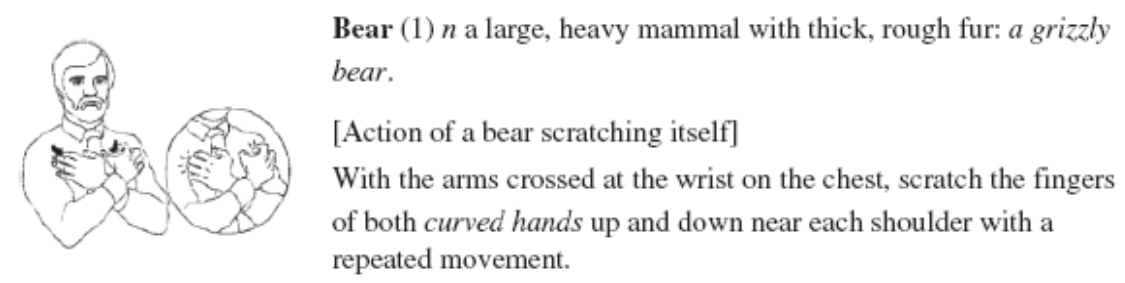

Figuur 5: Artikel uit 'n (gedrukte) ASL ${ }^{4}$-woordeboek (Costello 1998) (uit Zwitserlood 2010: 447)

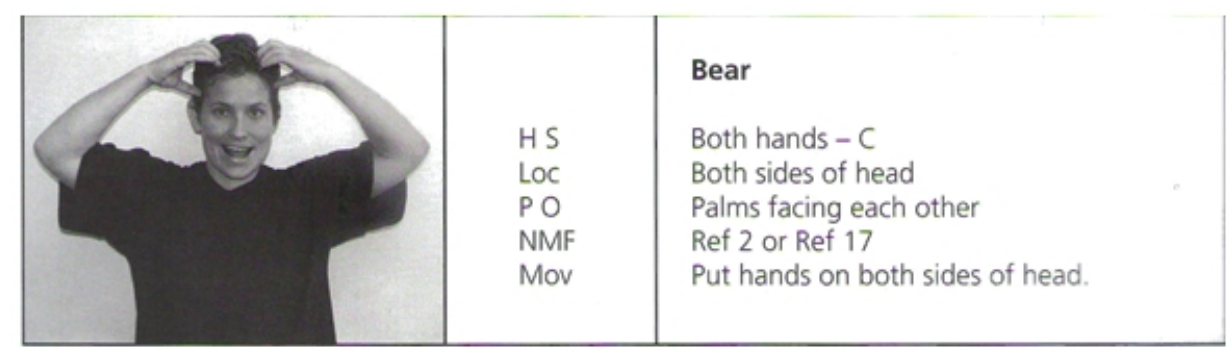

Figuur 6: Die artikel vir BEER uit (die gedrukte woordeboek) Finger Talk (Howard 2008) - die vier gebareparameters sowel as die niemanuele eienskappe (NME's) word aangedui

Gegewe die feit dat selfs 'n gebaretaalwoordeboek met relatief min artikels en inskrywings redelik lywig is of selfs verskeie boekdele beslaan, bevat die meeste gebaretaalwoordeboeke redelik min artikels in vergelyking met die 
woordeboeke van gesproke en geskrewe tale, en enige ekstra inligting word in die geskrewe taal gegee. Die aantal artikels in 'n woordeboek word egter gesien as 'n aanduiding van die kompleksiteit en gevolglik ook die status van 'n taal (Schermer 2004: 5), met die gevolg dat 'n beperkte aantal artikels die indruk van eenvoud of ondergeskiktheid skep.

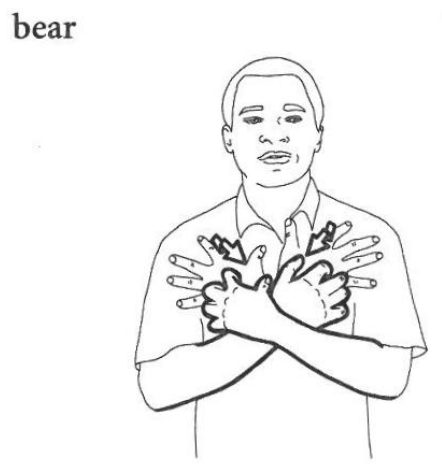

Figuur 7: Dié artikel vir die ASL-gebaar BEAR verskyn sonder enige verdere inligting in die gedrukte weergawe van die Gallaudet Dictionary of American Sign Language, alhoewel die meegaande CD-ROM wel ietwat meer inligting, soos sinonieme, saam met die video van die gebaar vertoon (Valli 2005: 38)

Die nadeel van gebareafbeeldings is dat hulle holistiese eenhede is wat moeilik is om te rangskik of om deur te soek, in vergelyking met die alfabetiese rangskikking van gesproke tale se woordeboeke. Slegs 'n paar tweetalige woordeboeke bevat afbeeldings van gebare sowel as 'n rangskikking gebaseer op gebarestruktuur, soos die Preliminary Signing Dictionary of Australian Sign Language (Johnston 1987), wat naas 'n alfabetiese lys Engels-na-Auslan artikels ook ' $n$ afdeling met Auslan-na-Engels bevat waarin gebare volgens die waardes van die gebareparameters gerangskik is. Vir die meeste gedrukte woordeboeke is hierdie moeite nie gedoen nie en hulle is geneig om steeds tweetalig, eenrigting en alfabeties gerangskik te wees volgens die woorde van die gesproke taal (Zwitserlood 2010: 448).

Verskeie notasiesisteme gebaseer op die vorm van gebare is oor die afgelope dekades ontwikkel. Die belangrikste hiervan is:

- die Stokoe-notasiesisteem (Stokoe et al. 1976),

— HamNoSys (Prillwittz et al. 1989), en

- ' $n$ sisteem wat bedoel is om as 'n ortografie van gebaretale te funksioneer, nl. SignWriting (SignWriting for Sign Languages 2011).

Elkeen van hierdie sisteme het stelle simbole vir die verskillende waardes van 
die gebareparameters en hierdie simbole word saamgevoeg of gekombineer om die gebarevorm daar te stel (sien figuur 8).

\begin{tabular}{|c|c|}
\hline Stokoe-notering & [] $\sqrt{ } C^{1} \sqrt{ } C_{x}^{v-}$ \\
\hline HamNoSys & 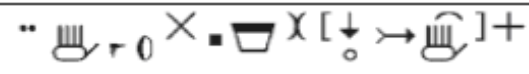 \\
\hline SignWriting & 茯苑 \\
\hline
\end{tabular}

Figuur 8: Weergawe van die ASL-gebaar BEAR in die drie notasiesisteme (aangepas uit Zwitserlood 2010: 449)

Waar die Stokoe- en HamNoSys-noterings meestal lineêr gerangskik en redelik abstrak is, is die SignWriting weergawe meer holisties en is die gebare makliker om te herken.

SignWriting is met die eerste oogopslag baie eenvoudiger as die ander twee noterings. Dit is egter ietwat misleidend, aangesien sommige inligting wat eksplisiet gemaak word, deur die ander twee noterings implisiet in die SignWriting weergawe is. In laasgenoemde is inligting oor die oriëntering van die hand altyd teenwoordig in die handvormsimbool. Bv. Wui duan dat die handpalm na die gebaregebruiker gedraai is; en dui onderskeidelik aan dat die palm na die kant of weg van die gebaregebruiker gedraai is. 'n Soortgelyke gebruik van kleurskakering dien om rigting van beweging aan te dui, wat nie in hierdie voorbeeld teenwoordig is nie. As resultaat van die kombinasie van handvorm en oriëntering in die handvormsimbole, en beweging en rigting in die bewegingsimbole, het SignWriting ' $n$ veel groter stel simbole as die ander twee sisteme (Zwitserlood 2010: 449).

Waar die SignWriting-notering redelik holistiese voorstellings vorm (alhoewel dit deur die kombinasie van simbole verkry word), is die Stokoe- en HamNoSys-noterings tot 'n sekere mate lineêr gerangskik (vgl. figuur 8). Die meer simultane aard van die gebarestruktuur laat verskillende rangskikkings van die simbole in elke sisteem toe, bv. handkonfigurasie kom eerste in HamNoSys gevolg deur plek van artikulasie, terwyl die Stokoe-sisteem die plek van artikulasie in die gebaar vóór handkonfigurasie aanbied. Die rangskikking is 'n resultaat van die keuse van die ontwerpers. Danksy die lineêre rangskikking van die simbole vergemaklik die Stokoe-notering en HamNoSys nogtans die rangskikking van gebarelemmas in 'n gedrukte woordeboek. Daar is egter, tot dusver, slegs een woordeboek wat uitsluitlik op die rangskikking van gebare volgens 
hul notering staatmaak en glad nie enige afbeeldings van die gebare gebruik nie (sien figuur 10), en dit is Stokoe et al. se Dictionary of American Sign Language on Linguistic Principles (1976) (Zwitserlood 2010: 450).

\begin{tabular}{|l|l|}
\hline \multicolumn{2}{|l|}{ Stokoe-notering } \\
\hline$[$ ] & hande by of naby bolyf \\
\hline$\sqrt{ }$ & voorarm \\
\hline $\bar{C}$ & gekromde vingers \\
\hline$\uparrow$ & arms kruis \\
\hline$\vee$ & afwaartse beweging \\
\hline$\cdot$ & een herhaling \\
\hline$X$ & artikulatore raak \\
\hline
\end{tabular}

\begin{tabular}{|c|c|}
\hline \multicolumn{2}{|c|}{ HamNoSys } \\
\hline 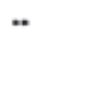 & $\begin{array}{l}\text { vorm en aksie van linkerhand } \\
\text { weerspieèl dié van die regterhand }\end{array}$ \\
\hline Ш & vingers en duim uitgestrek en reguit \\
\hline$r$ & $\begin{array}{l}\text { vingers (van die regterhand) wys na } \\
\text { links bo }\end{array}$ \\
\hline 0 & palm (van die regterhand) na links \\
\hline X & hande of arms gekruis \\
\hline . $\square$ & (regterhand) aan linkerkant van skouers \\
\hline$x$ & kontak met liggaam \\
\hline$\downarrow$ & afwaartse beweging \\
\hline$\circ$ & klein beweging \\
\hline$\longmapsto$ & verandering in handvorm (of oriëntering) \\
\hline$\frown$ & gekromde [vinger of vingers] \\
\hline+ & een herhaling \\
\hline
\end{tabular}

Figuur 9: Verklaring van die Stokoe- en HamNoSys-noteringsimbole (aangepas uit Zwitserlood 2010: 450)

\section{[] $\mathrm{JC}^{*} \mathrm{JC} \times \mathrm{x}^{\text {. }}$}

(imitative of bear hug; arms crossed on chest, dez claw downward) $\mathrm{N}$ bear.

Figuur 10: Artikel vir die gebaar vir BEER (Stokoe et al. 1976: 192) 
Die Dictionary of British Sign Language/English (Brien 1992) gebruik ook 'n aangepaste weergawe van die Stokoe-sisteem om die gebare wat deur die lemmas voorgestel word, te beskryf (sien figuur 11), maar alhoewel die gebare volgens parameterwaardes gerangskik is, volg die rangskikking nie die lineêre rangskikking in die lemmanotering nie, en die gebare is omvattend gerangskik volgens handvorm > plek > oriëntering > beweging, en die spesifieke waardes van hierdie parameters. Hierdie woordeboek verskaf ook foto's van die gebare wat van pyle en ander simbole voorsien is om die aktiwiteit van die gebaar aan te dui (Zwitserlood 2010: 451):
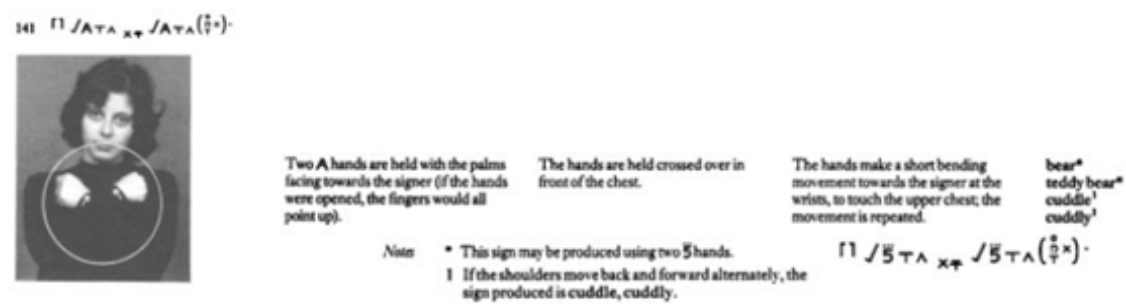

Figuur 11: $\quad$ Artikel vir die gebaar vir BEER (BSL 5 ) (Brien 1992: 182-183)

Let daarop dat daar 'n verskil is tussen die ASL- en BSL-gebare vir BEER, sowel as vir die SASL-gebaar in figuur 6.

Die noterings het eenvoudig nie posgevat as algemene skryfvorme van gebaretaal nie. Die rede hiervoor is waarskynlik dat ' $n$ gebruiker eers moet leer hoe om die tekens te ontsyfer en die sisteme vereis dus 'n hoë vlak van 'n spesifieke soort visuele geletterdheid. 'n Mens sou kon argumenteer dat geskrewe en gesproke taal ook 'n hoë mate van spesifieke of gespesialiseerde geletterdheid vereis voordat die gebruiker dit op 'n sinvolle manier kan ontsluit, maar die meeste gebruikers van gebaretale is eerder geneig om 'n meer intuïtiewe, voor die hand liggende vorm van visuele voorstelling te verkies, waarskynlik weens die beperkte toepassing van hierdie sisteme: 'n persoon wat in 'n geskrewe taal geletterd is, kan elke dag met groot gemak en in enige situasie lees of skryf, maar die noteringsisteme word feitlik uitsluitlik in woordeboeke gebruik, en is gewoonlik nie moontlik om sonder die hulp van gespesialiseerde programmatuur te produseer nie.

\section{Elektroniese gebaretaalwoordeboeke}

Die ontwikkeling van elektroniese gebaretaalwoordeboeke bied 'n oplossing vir die probleme wat met voorstelling ondervind word en het akkurate voorstelling moontlik en bekostigbaar gemaak deur middel van vooruitgang in videoprosessering en rekenaartegnologie. Sulke woordeboeke kan digitale video's van die gebare verskaf, wat die gebaar se aktiwiteite veel beter voorstel, insluitende die dele wat nie op die hande is nie, soos mondbewegings en 
gesigsuitdrukkings, alhoewel hulle (nog) nie die voorstelling van die gebruik van driedimensionele ruimte toelaat nie (Zwitserlood 2010: 451). Met die vinnige vooruitgang wat ten tyde van hierdie skrywe ten opsigte van driedimensionele tegnologie gemaak word - dink maar aan al die 3D-televisies, -teaters, -rekenaarspeletjies, ens. wat reeds beskikbaar is - sal dit egter nie veel langer 'n leemte bly nie.

Die meeste, waarskynlik eerder alle, gebaretaalwoordeboeke bied 'n woordsoekmetode. In gedrukte gebaretaalwoordeboeke is daar gewoonlik (a) 'n alfabetiese lys geskrewe lemmas met ' $n$ verwysing na die toepaslike gebaar, of (b) die gebare is gerangskik as vertaalekwivalente van die lemmas in die geskrewe taal. In elektroniese gebaretaalwoordeboeke is dit ook moontlik om deur die databasis te soek met behulp van 'n geskrewe woord en dan 'n artikel as soekresultaat te vind waarin die geskrewe woord as vertaalekwivalent van die gebaarlemma aangebied word of andersom. In die era van elektroniese leksikografie is dit egter ook meer en meer die geval dat elektroniese gebaretaalwoordeboeke 'n gebaarsoekmetode aanbied.

'n Begrip van die fonemiese eienskappe van gebare laat ons sien dat elke gebaar uit sekere elemente of parameters bestaan, nl. handvorm, beweging, palmoriëntering en plek (in die gebareruimte). Sommige gebaretaalwoordeboeke, soos die Auslan Dictionary (Johnston 1989) maak van een of meer van hierdie kenmerke gebruik om 'n vloeidiagramtipe soekproses vir gebare te skep: die gebruiker word eerstens gevra of die gebaar wat gesoek word, met een of twee hande gemaak word. Indien dit twee hande is, word gevra of die hande simmetries of asimmetries ten opsigte van hul vorm en beweging is. Dan word die gebruiker gevra om die handvorm te identifiseer, sowel as die plek waar die gebaar in die gebareruimte afspeel. $\mathrm{Na}$ afloop van hierdie soekproses behoort die gebruiker 'n kort lysie moontlike gebare te hê om van te kies.

Dit is standaardpraktyk onder die meeste gebaretaalwoordeboeke wat vandag aanlyn of digitaal beskikbaar is, om gebruik te maak van 'n soekmetode volgens handvorm (en o.a. dikwels ook plek waar die gebaar geartikuleer word). Enkele voorbeelde van tweetalige internetwoordeboeke - waarin dit dus moontlik is om gebare op te soek asook woorde - van verskillende gebaretale word ter illustrasie genoem. Die soektogte wat hieronder genoem word, is na willekeur gedoen en nie met enige spesifieke gebaar of soekresultaat in gedagte nie, aangesien die skrywer geen kennis van die betrokke gebaretale het nie.

Die internetwoordeboek van Deense Gebaretaal (Center for Tegnsprog 2008 ) bied ' $n$ totaal van vier soekkriteria vir gebare aan (afgesien van ' $n$ woordsoektog): die handvorm van (1) een of (2) twee hande kan gekies word, (3) die plek waar die gebaar geartikuleer word, kan ingesluit word asook (4) die tema waartoe die gebaar behoort. Die gebruiker is nie verplig om van al vier soekkriteria gebruik te maak nie, alhoewel die soekresultate aansienlik verminder hoe meer kriteria geselekteer word. Deur bv. slegs die handvorm van een hand as die C-handvorm te kies, word 42 gebare as soekresultate aangebied. Deur die gesig/kop as die plek van die gebaar te selekteer, verminder die resultate na 10. Deur "Natuur" as die tema te selekteer, word 3 gebare in die soekresultate 
gelewer. Die woordeboek bevat ongeveer 2000 gebare, wat 'n relatiewe klein aantal lemmas in vergelyking met die meeste woordeboeke van ander gebaretale is, maar dit dien as 'n goeie aanduiding van die effektiwiteit van 'n trapsgewyse of verfynbare soektog waar soekkriteria bygevoeg kan word indien die resultate te veel is. Verfynbare soektogte, veral in die geval van 'n groot aantal soekresultate, is een van Almind (2005: 39) se ontwerpkriteria vir elektroniese woordeboeke. Die voorbeelde van soekprosesse wat hieronder uit ander tweetalige gebaretaalwoordeboeke genoem word, voldoen almal aan hierdie vereiste.

Die Digitaal Vlaamse Gebarentaal-Nederlands/Nederlands-Vlaamse Gebarentaal woordenboek (Van Herreweeghe et al. 2004) bevat ongeveer 7458 gebarelemmas en bied ook handvorm en plek/aanraking as soekkriteria aan. Deur aanvanklik slegs een handvorm te kies, nl. die F-hand, word 19 soekresultate gelewer. Deur die kop/gesig as plek te selekteer en "aanraak" as die tipe aanraking (in vergelyking met die ander tipes aanraking wat voorsien word, nl. "geen", "gryp", "tussen/in", "slaan", "vee" en "vryf") word die resultate na 'n totaal van 1 gebaar verminder.

Die internetwoordeboek van Finse Gebaretaal (Kuurojen Liittory 2003) bied vier soekkriteria vir gebare aan, nl. handvorm, aantal hande (een of twee), plek en beweging. Deur slegs die C-handvorm as soekkriterium te selekteer, word 17 gebare in die soekresultate gelewer. Indien die soekprosedure aangepas word om na eenhandige gebare met die C-handvorm te soek, word 9 gebare verkry. Deur een stap verder te gaan en die neutrale gebareruimte as plek te selekteer, word die soeklys na 2 resultate verkort. Dit is nie duidelik hoeveel gebare in die woordeboek opgeneem is nie, en alhoewel die soektog redelik intuïtief volgens die prentjies op die bladsy kon geskied, word al die teks op die webblad slegs in Fins aangebied.

Die internetwoordeboek van Italiaanse Gebaretaal (e-LIS) (Institute for Specialised Communication and Multilingualism 2005) bevat op die oomblik ongeveer 200 gebare en bied ook 'n soekprosedure volgens die parameters handvorm, oriëntasie, plek en beweging aan. 'n Aanvanklike soektog na gebare met die C-handvorm lewer 21 resultate ('n maksimum van agt resultate word per bladsy vertoon). Ten tyde van 'n besoek aan die webblad op 1 September 2011 het die verfyning van die soektog skynbaar nie korrek gefunksioneer nie, aangesien ' $n$ soektog na die C-handvorm met ' $n$ palmoriëntasie na links steeds 21 resultate gelewer het, asook 'n soektog met die bogenoemde parameters plus die boonste gedeelte van die borskas as plek. Dit is natuurlik heeltemal moontlik dat die spesifieke gebruiker se gebrekkige kennis van die Italiaanse instruksies die soektog laat misluk het eerder as ' $n$ fout op die webblad self.

Die internetwoordeboek van Nieu-Seelandse Gebaretaal (McKee et al.) bevat ongeveer 4000 NZSL-gebare. Die gebruiker kan 'n soektog doen met behulp van 'n Engelse woord, 'n gebaar (volgens handvorm en plek) en ook 'n gevorderde soekfunksie, wat behalwe die selektering van handvorme en plek ook 'n seleksie uit 'n lys tematiese onderwerpe en gebruiksetikette (argaïes/ verouderd, neologisme, obseen, informeel of ongewoon) bied. Deur die velde handvorm, plek en gebruiksetiket leeg te laat terwyl slegs 'n tematiese kate- 
gorie gekies word, is dit ook moontlik om die totale aantal artikels in elk van die tematiese kategorieë (met 'n maksimum van 9 resultate per bladsy en in alfabetiese volgorde) te sien. Die beperking van die aantal soekresultate wat op 'n bladsy vertoon word, voldoen aan Almind se vyfde ontwerpvereiste vir elektroniese woordeboeke (2005: 39).

Die aanlyn woordeboek van Oostenrykse Gebaretaal (LedaSila) (Zentrum für Gebärdensprache und Hörbehindertenkommunikation) bied benewens die gebruiklike soekkriteria plek, handvorm en tema ook die "tipe gebaar" (eenhandig of tweehandig, simmetries of asimmetries) en die landstreek waarin die gebaar voorkom as soekkriteria aan. Dit word nie aangedui presies hoeveel gebare in totaal in die woordeboek opgeneem is nie, maar 'n soektog na alle eenhandige gebare lewer 7066 resultate. 'n Volgende soektog waarby die D-handvorm (geslote vuis met uitgestrekte wysvinger) ingesluit word, lewer 3 resultate.

Soos uit die bostaande bespreking gesien kan word, is dit algemene praktyk in gebaretaalleksikografie om 'n gebaar volgens handvorm op te soek en maak die elektroniese formaat van gebaretaalwoordeboeke dit aansienlik makliker om ' $n$ tweetalige tweerigtingwoordeboek van gebaretaal en 'n geskrewe taal saam te stel. Die elektroniese soekproses volgens handvorm is ook baie meer gebruikersvriendelik as die soekproses aan die hand van notering wat bv. in Stokoe et al. se woordeboek (1976) gebruik is.

Die soektog na gebare op grond van gebareparameterwaardes is dus veel makliker in 'n elektroniese as 'n gedrukte woordeboek. Die woordeboeksamestellers moet steeds parameterwaardes aan die gebarevideo's koppel, maar daar is nie die tipiese probleem van rangskikking nie. Die gebruikers van so 'n woordeboek moet weg van die gebaar as 'n geheel abstraheer om die gebareparameters in 'n soektog te kan gebruik, maar die aanbieding van sulke waardes kan op 'n duidelike, gebruikersvriendelike manier gedoen word. Die aanbieding van gebare is baie duideliker as in enige gedrukte woordeboek, aangesien ' $n$ video, sowel as ' $n$ tweedimensionele prentjie gesien kan word (Zwitserlood 2010: 453, 454).

Dit is harde werk om sulke omvattende woordeboeke saam te stel, en om daardie rede is daar op die oomblik net 'n handjievol, alhoewel die getal stadigaan groei. Baie aanlyn gebaretaalwoordeboeke is steeds eenrigting, wat beteken hulle gee slegs gebarevertaling vir woorde van 'n gesproke taal in 'n een-toteen-verhouding, soos bv. die American Sign Language Browser (Michigan State University 1997) (Zwitserlood 2010: 454), en sonder verdere inskrywings vir die lemma in die gebaretaal, soos die Gallaudet Dictionary of American Sign Language (Valli 2005). Laasgenoemde woordeboek verskaf in die boekvorm slegs ' $n$ alfabetiese lys Engelse soekwoorde met 'n bygaande skets, sonder enige verdere data. Op die meegaande CD-ROM lei die geskrewe soekwoord uit die alfabetiese lys na 'n video van die gebaar, en in sommige gevalle word sinonieme (in die gesproke taal) verskaf, maar geen verdere data word in ASL gegee nie. Dit is ook nie moontlik om 'n gebaar op te soek nie.

Elektroniese woordeboeke het steeds 'n redelike klein databasis, met ongeveer 2000 tot 5000 lemmas (Zwitserlood 2019: 454). 


\section{'n Model vir 'n nuwe elektroniese gebaretaalwoordeboek}

Dowes verteenwoordig 'n groep teikengebruikers wat nog nie oor 'n gevestigde woordeboekkultuur beskik nie. Die tipiese Dowe persoon - daar is natuurlik altyd uitsonderings - behaal slegs lae vlakke van geletterdheid in die geskrewe/gesproke taal, wat hulle tweede taal is. Die ideaal is dus om 'n woordeboekkultuur te skep by 'n groep jong gebruikers, nl. leerders in die grondslagfase, deur middel van 'n tweetalige tweerigtinggebaretaalwoordeboek wat spesifiek op hulle belangstellings en behoeftes gerig is. Fourie (2013) se model is ontwerp vir die De la Bat Skool vir Dowes in Worcester, spesifiek vir leerders in die grondslagfase. Daar word beplan dat die voorgestelde grondslagfasewoordeboek deur verdere woordeboeke vir die intermediêre en senior fases opgevolg en aangevul sal word, sodat leerders deur hulle hele skoolloopbaan toegang tot 'n woordeboek sal hê wat geskik is vir hulle behoeftes. Die skool beskik tans oor geen skoolwoordeboek nie en gebruik geskrewe klaslyste, wat slegs die Afrikaanse teikenwoorde in die onderskeie leerareas of temas lys. Die geskrewe lyste maak dit egter nie moontlik om 'n visuele skakel te vorm met die betrokke konsep wat deur 'n woord uitgedruk word nie, en ook nie om aan te dui watter gebaar of gebare by die konsep en woord pas nie. Daar bestaan dus 'n behoefte aan 'n elektroniese produk wat 'n visuele soekmetode vir 'n konsep bied, sowel as 'n soekmetode vir 'n gebaar en 'n woord.

Daar is heelwat geskrewe woordeboeke op die mark wat op grondslagfaseleerders gemik is en wat ook tematiese soekareas of kategorieë insluit, aangesien dit makliker vir jong gebruikers is om konsepte op te soek binne die leerareas wat in die klaskamer behandel word. Voorbeelde van sulke woordeboeke sluit in die Longman Grondslagfasewoordeboek Afrikaans/Engels (2010) (voorts LGFW) en die Oxford First Bilingual Dictionary Afrikaans + English (2010). Woordeboeke soos dié verskaf gewoonlik 'n indeks in albei tale agterin die woordeboek, en in die geval van die Longman-woordeboek is daar ook 'n Afrikaanse alfabetiese afdeling waarin 'n definisie vir elke woord tesame met 'n voorbeeldsin in Afrikaans, asook 'n Engelse vertaling van die voorbeeldsin wat die gebruiker help om sy of haar addisionele taal te verstaan en te gebruik. Prentjies word ook in hierdie afdeling gebruik om woorde te kontekstualiseer. Woorde wat tot spesifieke tematiese kategorieë behoort of daartoe sou kon behoort (maar nie noodwendig in die betrokke tematiese kategorieë ingesluit is nie), word daarheen terugverwys sodat die alfabetiese woordelys steeds gekontekstualiseer bly.

Fourie (2013) se model maak voorsiening vir 'n elektroniese woordeboek wat op drie maniere soekbaar is: volgens konsep (deur 'n versameling tematiese kategorieë wat deur prentjies voorgestel word), volgens gebaar (deur 'n proses van parameterkeuses) en volgens woord. Die soekresultate sal altyd identies wees, ongeag die soekmetode. Op hierdie manier ontstaan 'n trippellemma wat bestaan uit 'n ostensiewe lemma wat deur die prentjie verteenwoordig word, 'n tweede lemma wat deur die gebaar (as skets en/of video) verteenwoordig word en 'n derde lemma wat uit die geskrewe woord bestaan soos voorgestel in figuur 12. 


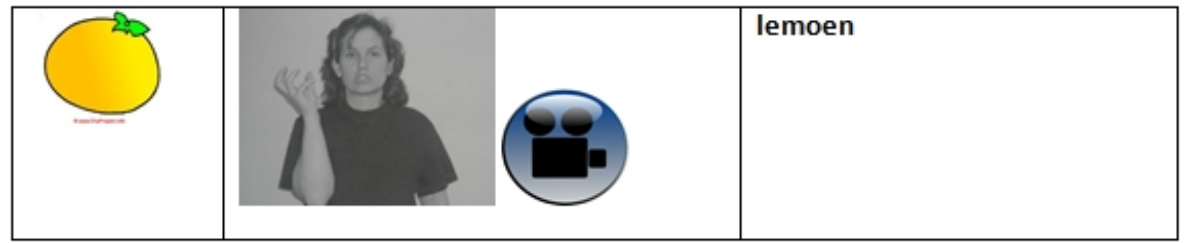

Figuur 12: Hipotetiese voorstelling van die voorkoms van die drievoudige lemma (Fourie 2013: 349)

Die model stel ook 'n parallelle mikro-argitektuur voor waarin nie net die lemmata langs mekaar aangebied word nie, maar ook die definisies; sien figuur 13.

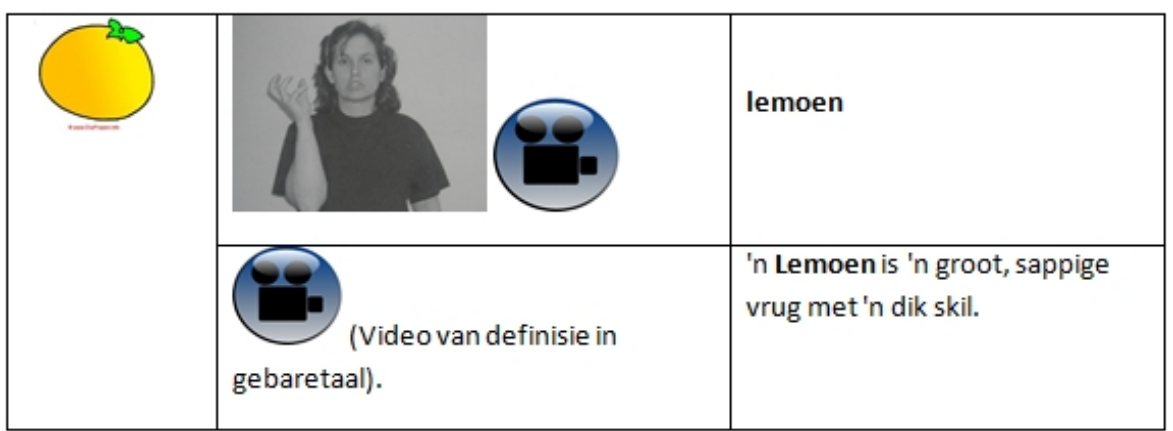

Figuur 13: Hipotetiese aanbieding van 'n definisie in albei tale (Fourie 2013: 358)

In die bostaande voorbeeld is slegs die gebruik van parallelle definisies in albei tale gedemonstreer, nie die volledige mikrostruktuur nie. Die geskrewe definisie is uit die LGFW (2010: 55). Die gebaretaaldefinisie en die geskrewe definisie sal met mekaar moet ooreenstem om die inhoud van die mikrostruktuur tweetalig te maak. Voorbeeldsinne kan op 'n soortgelyke manier hanteer word.

Verdere besonderhede van die model sal in komende publikasies bekend gemaak word. Op hierdie stadium is dit belangrik om kennis te neem dat die model voorsiening maak vir 'n situasie waarin 'n Dowe gebruiker nie in enige geskrewe taal geletterd hoef te wees om 'n woordeboek in sy of haar eie taal te gebruik nie. Terselfdertyd sal ' $n$ horende gebruiker in staat wees om ' $n$ gebaar op te soek waarvan die betekenis onbekend is, soos wanneer ' $n$ gebaar in ' $n$ gesprek of onbekende konteks opgemerk word. Gebruikers sal egter ook die opsie hê om van konsep na gebaar of woord te beweeg deur middel van 'n visuele tematiese soekmetode. Dus hoef gebruikers eintlik in geen taal geletterd te wees om die woordeboek effektief te gebruik nie.

\section{Slot}

Die ontwikkeling van gebaretaalleksikografie was in die verlede grootliks onder- 
hewig aan verskillende vooroordele en beperkinge. Dit was dikwels nie nodig geag om 'n tweetalige woordeboek saam te stel waarin dit ook moontlik is om 'n gebaar op te soek nie aangesien tweetalige gebaretaalwoordeboeke grotendeels gemik was op horende persone wat die taal wou of moes leer. Daarby was dit baie moeilik vanweë die aard van gedrukte woordeboeke en die gebrek aan 'n ortografiese vorm van gebaretaal, om gebare op 'n manier voor te stel én te rangskik sodat hulle opgesoek kan word sonder om van 'n geskrewe soekterm gebruik te maak. Daar is wel notasiesisteme ontwikkel in 'n poging om hierdie probleem te omseil, maar hierdie sisteme het nooit by gewone gebruikers wyd byval gevind nie. Die gebruik van elektroniese media en platforms om gebaretaalwoordeboeke te ontwikkel en aan te bied het egter gesorg vir ' $n$ revolusie in gebaretaalleksikografie. Dit is nie meer ongewoon om elektroniese gebaretaalwoordeboeke te vind waarin nie net 'n woord nie, maar ook 'n gebaar soekbaar is, gewoonlik volgens een of meer van die gebaar se parameters, soos handvorm. Sulke woordeboeke maak dit moontlik vir 'n Dowe gebruiker om direkte toegang tot sy of haar eerste taal (gebaretaal) te bekom sonder enige kennis van die tweede taal (die geskrewe taal). Aangesien daar nog nie ' $n$ gevestigde woordeboekkultuur onder Dowe gebruikers bestaan nie, sal dit die ideale geleentheid wees om 'n jong generasie teikengebruikers van ' $n$ woordeboek te voorsien wat op hulle spesifieke behoeftes en belangstellings gerig is. Fourie (2013) voorsien 'n model vir 'n elektroniese tweetalige grondslagfasewoordeboek van Suid-Afrikaanse Gebaretaal en Afrikaans waarin dit nie net moontlik is om van 'n woord na ' $n$ gebaar of van 'n gebaar na 'n woord te beweeg nie, maar ook van 'n konsep na 'n gebaar of woord. Behalwe woorden gebaarsoekmetodes word daar ook in die model voorsiening gemaak vir ' $n$ visuele, tematiese soekmetode. Dit maak dit vir die gebruiker moontlik om toegang tot die woordeboek te verkry sonder om gebruik te maak van enige van die twee tale wat aangebied word. Die soekresultate vertoon identies ongeag die soekmetode wat gebruik word, wat verseker dat die drie soekmetodes volledig met mekaar sluit en dat elke soekmetode onafhanklik van die ander gebruik kan word om toepaslike soekresultate te lewer.

\section{Eindnote}

1. Die gebruik van die kleinletter in doof dui op oudiologiese of patologiese doofheid, terwyl die hoofletter in Doof dui op kulturele Doofheid.

2. SASL - South African Sign Language (Suid-Afrikaanse Gebaretaal). Engelse afkortings is in die teks behou omdat dit die bekendste en gebruiklikste in die literatuur is.

3. Die NME's dra geweldige grammatikale waarde - sonder gesigsuitdrukking is die meeste gebare ongrammatikaal en vir ' $n$ Dowe onverstaanbaar. Dit is ook gewoonlik een van die sterk punte van kritiek teen die meeste gebarewoordeboeke dat NME's nie genoegsaam uitgebeeld word nie.

4. ASL - American Sign Language (Amerikaanse Gebaretaal).

5. BSL - British Sign Language (Britse Gebaretaal). 


\section{Bibliografie}

Almind, R. 2005. Designing Internet Dictionaries. Hermes, Journal of Linguistics 34: 37-54.

Brien, D. (Red.). 1992. Dictionary of British Sign Language/English. Londen: Faber\&Faber.

Center for Tegnsprog. 2008. Ordbog over Dansk Tegnsprog. (The Danish Sign Language Dictionary.) http://www.viittomat.net/http://www.tegnsprog.dk/.

Costello, E. 1998. Random House Webster's American Sign Language Dictionary. New York: Gallaudet University Press.

Fourie, H. 2013. 'n Leksikografiese model vir 'n elektroniese tweetalige grondslagfasewoordeboek van SuidAfrikaanse Gebaretaal en Afrikaans. Ongepubliseerde D.Litt.-proefskrif. Stellenbosch: Universiteit Stellenbosch.

Gouws, R., L. Potgieter en S. Burgess (Reds.). 2010. Longman Grondslagfasewoordeboek Afrikaans/ Engels. Kaapstad: Maskew Miller Longman.

Hiles, L. en I. Redelinghuijs (Reds.). 2010³. Oxford First Bilingual Dictionary: Afrikaans + English. Kaapstad: Oxford University Press.

Howard, S. 2008. Finger Talk: South African Sign Language (SASL) Dictionary. Gillitts: Fulton School for the Deaf.

Institute for Specialised Communication and Multilingualism. 2005. Electronic Bilingual Dictionary Italian Sign Language-Italian. http://elis.eurac.edu/index_en.

Johnston, T. 1987. Preliminary Signing Dictionary of Australian Sign Language. Adelaide: TAFE National Centre for Research and Development.

Johnston, T. 1989. Auslan Dictionary: A Dictionary of Australian Sign Language (Auslan). Adelaide: TAFE National Centre for Research and Development.

Kuurojen Liittory. 2003. Suvi Suomalaisen viittomakielen verkosanakirja. (Finnish Sign Language Dictionary.) http://suvi.viittomat.net.

Landau, S.I. 1984. Dictionaries. The Art and Craft of Lexicography. New York: The Scribner Press.

Malm, A. (Red.). 1998. Suomalaisen viitomakielen perussankirja. Helsinki: Libris Oy.

McKee D., R. McKee, S. Pivac Alexander, M. Vale en L. Pivac (Reds.). 2011. Online Dictionary of New Zealand Sign Language. Deaf Studies Research Unit, Victoria University of Wellington, New Zealand. http://nzsl.vuw.ac.nz/nzsl.

Mesthrie, R., J. Swann, A. Deumert en W. L. Leap (Reds.). 2000. Introducing Sociolinguistics. Edinburgh: Edinburgh University Press.

Michigan State University. 1997. American Sign Language Browser. http://aslbrowser.commtechlab. msu.edu/index.html.

Nieder-Heitmann, N. 1980. Praat met die dowes: 'n Visuele handboek met gestandaardiseerde gebare vir Dowes in Suid-Afrika. Pretoria: Staatsdrukker.

Penn, C., D. Ogilvy-Foreman, D. Simmons and M. Anderson-Forbes. 1992-1994. Dictionary of Southern African Signs for Communicating with the Deaf. 5 dele. Pretoria: Raad vir Geesteswetenskaplike Navorsing.

Prillwitz, S., R. Leven, H. Zienert, T. Hanke en J. Henning. 1989. HamNoSys. Version 2.0. Hamburg Notation System for Sign Language: An Introductory Guide. Hamburg: Signum Verlag.

Radutzky, E. (Red.). 1992. Dizionario bilingue elementare della Lingua Italiana dei Segni. Rome: Edizioni Kappa.

Schermer, T. 2004. Sign Language Lexicography. Stichting Nederlands Gebarencentrum. http:// www.gebarencentrum.nl/publicaties.asp. 
SignWriting for Sign Languages. 2011. www.signwriting.org [5 Junie 2011].

Stokoe, W.C., D.C. Casterline en C.G. Croneberg. 1976. A Dictionary of American Sign Language on Linguistic Principles. Nuwe uitgawe. Washington DC: Gallaudet University Press.

Valli, C. (Red.). 2005. The Gallaudet Dictionary of American Sign Language. Washington, DC: Gallaudet University Press.

Van Herreweeghe, M., S. Slembrouck en M. Vermeerbergen. 2004. Digitaal Vlaamse GebarentaalNederlands/Nederlands-Vlaamse Gebarentaal woordenboek. http://gebaren.ugent.be/.

Zentrum für Gebärdensprache und Hörbehindertenkommunikation. s.j. LedaSila - Lexical Database for Sign Languages. http://ledasila.uni-klu.ac.at.

Zwitserlood, I. 2010. Sign Language Lexicography in the Early 21st Century and a Recently Published Dictionary of Sign Language of The Netherlands. International Journal of Lexicography 23(4): 443-476. 